\title{
Gender as Individual Risk Factor for Elderly Abuse: Findings from First National Prevalence Study in Macedonia
}

\author{
Marijana Markovik $^{1^{*}}$, Dimitrinka Jordanova Peshevska ${ }^{2}$ \\ ${ }^{1}$ Institute for Sociological, Political and Juridical Research, Ss Cyril and Methodius University of Skopje, Skopje, Republic of \\ Macedonia; ${ }^{2}$ World Health Organization, Country Office Skopje, Republic of Macedonia
}

\begin{abstract}
Citation: Markovik M, Jordanova Peshevska D Gender as Individual Risk Factor for Elderly Abuse: Findings from First National Prevalence Abuse: Findings from First National Prevalence
Study in Macedonia. OA Maced J Med Sci. Study in Macedonia. OA Maced J Med Sci.
$2014 \quad$ Jun $\begin{array}{llr}2014 & \text { Jun } 15 ; & 2(2): 373-378 \\ \text { http://dx.doi.org/10.3889/oamjms.2014.064 }\end{array}$ Key words: elder abuse; elder neglect; gender risk factor; Republic of Macedonia.

"Correspondence: Marijana Markovik. Ss Cyril and Methodius University of Skopje, Institute for Sociological, Political and Juridical Research, Skopje, Bulevar Partizanski Odredi bb, 1000 Skopje, Republic of Macedonia. E-mail: marijana@isppi.ukim.edu.mk

Received: 28-Mar-2014; Revised: 06-May2014; Accepted: 08-May-2014; Online first: 26-May-2014

Copyright: (c) 2014 Markovik \& Jordanova Peshevska. This is an open access article distributed under the terms of the Creative Commons Attribution License, which permits unrestricted use, distribution, and reproduction in any medium, provided the original author and source are credited.

Competing Interests: The authors have declared that no competing interests exist.
\end{abstract}

\begin{abstract}
BACKGROUND: National prevalence study of elderly abuse in Macedonia intended to explore prevalence and risk factors of elder abuse and neglect. This paper is focused on influence of the gender as individual risk factor, according to ecological model, on elderly abuse and neglect.

METHODS: Culturally validated questionnaire and Geriatric Depression scale was used for data collection. Mini Mental State Examination (MMSE) test, was used for sample selection. Cutting score was 20. The research was conducted through face-to-face interviews on the sample of 960 respondents aged 65 and over.

RESULTS: Evidenced were $32 \%$ abused and neglected from representative sample, living in private households, $19 \%$ of abused was female. In Macedonian study women are 1.6 times often victims of abuse than man. Only female respondents reported sexual abuse.
\end{abstract}

CONCLUSION: Being female is risk factor for being exposed on any type of abuse and neglect, excluding financial abuse.

\section{Introduction}

According to estimates in 2005, future life expectancy at 65 years was 20 years for women and 17 for men [1].Of over-75-year-olds, women make up two thirds of the population; of over-85-year-olds the proportion of women is $71 \%$ [1]. However, the difference between healthy life years for women and men was less than one year [2, 3].

There are many terms which have been used to describe "old age". According to the definition for elderly people given by $\mathrm{WHO}$, the critical age for classification as old is 65 years [4,5]. This definition is not universal, however. Most developed countries accept the chronological age of 65 years and over as a definition of elderly, but in some parts of the developing world, for example, this is not the case [5].
Abuse of older people has only recently been recognized as a global problem. International Network for Prevention of Elder Abuse's (INPEA) advocacy work and the emphasis given to elder abuse prevention by the World Health Organization have contributed significantly to raising awareness worldwide [6].

One commonly used definition of elder abuse is that adopted by WHO and INPEA: "Elder abuse is a single or repeated act, or lack of appropriate action, occurring within any relationship where there is an expectation of trust, which causes harm or distress to an older person" [4, 6]. According to WHO, it can take the various forms of physical, psychological, emotional, sexual and financial abuse. It can also result from intentional or unintentional acts. In the different studies and literature [4, 7] the following types of elder abuse have been identified: physical 
abuse (use of physical force that may cause bodily injury, physical pain, or impairment); psychological/emotional abuse (distress caused through verbal or nonverbal acts); financial/material abuse (the illegal or improper use of an elderly individual's funds, property, or assets); sexual abuse (nonconsensual sexual contact of any kind with an elderly individual); neglect (refusal or failure to fulfil any part of an individual's obligations or duties to an elder); neglect also may include failure of an individual who has responsibilities to provide care for an elderly individual.

Several theoretical approaches attempt to explain the causes of elder abuse. WHO accepted the ecological theory model which explores the interactions between the individual and contextual factors? It considers abuse as the result of the complex interplay between a person's individual characteristics (biology, personal history) close interpersonal relationships, characteristics of the community in which the person lives or works and societal factors such as policies and social norms. The ecological model allows elder abuse to be linked to broader social issues [8].

In Macedonia, a systematic scientific approach to elder woman abuse has been lacking until recently. There are general findings about family violence toward woman in Macedonia. According to these findings, every second woman in Macedonia is a victim of psychological violence, every sixth woman experienced physical violence and almost every tenth woman has been victim of sexual abuse [9]

This study was a community-based household survey at national level. The general objective of this study was to explore the phenomenon of elder maltreatment (of people aged 65 years and over) in Macedonia. The principal goal of this study was to collect data and determine the magnitude, scope and extent of the problem of elder abuse and to explore different types of elder maltreatment. The methodology used enables our findings to be compared with studies from other European Region countries.

Main hypothesis in this paper was that gender (being female) is a relevant risk factor on individual level, according to ecological model of elderly abuse, for elder abuse and neglect.

\section{Methods}

\section{Instruments}

This national prevalence study on elder maltreatment used two questionnaires that had already been developed and applied in research [10, $11]$.

The questionnaire was translated into the Macedonian and Albanian languages. Qualitative analysis of the final questionnaire was undertaken with a focus group of experts and the Scientific Committee of the study. The final version of the questionnaire used in this study contains questions addressing: sociodemographic factors; life-style factors (smoking, alcohol use, diet); diseases; physical health and mental health (using the Geriatric Depression Scale); questions about abuse/neglect; perpetrators and reactions after abuse/neglect. Depressionwas measured using the Geriatric Depression Scale. This scale was developed as a basic screening instrument for depression in old age [12]. Serbian translation of the short version of this scale, with 15 items [13].

\section{Sample}

The study was a community based household survey at national level. The target population for this study was a sample of people aged 65 years or older, living in private households. Desired sample was 960, which represents $0.4 \%$ of the total number of people over the age of 65 years (the percentage of people aged over 65 years in the Macedonian population is $11.7 \%$ [14]). This sample included the appropriate ratio of men and women and was constructed according to the following criteria: gender, ethnic background, municipality, city/village and region [15]. Sampling was carried out by quota. The number of respondents in each quota depended on population distribution.

The selection criterion for involvement in the study was absence of mental impairment to participation (such as dementia). Potential participants were screened using a series of questions from the Mini-Mental State Examination-MMSE (cutting score was 20) $[16,17,18]$. Older people with high scores were included in the sample (only 23 respondents have been excluded from this research). Table 1 represents the distribution of the older population in the Macedonia according to age and gender, presented in numbers and percentages.

Table 1: Population in the country according to gender and age and sample size.

\begin{tabular}{lccc}
\hline Population & Total & Male & Female \\
aged 65 and over & $239756^{*}$ & 106837 & 132919 \\
$\%$ & 100.0 & 44.6 & 55.4 \\
Sample size & Total & Male & Female \\
aged 65 and over & 960 & 430 & 530 \\
$\%$ & 100.0 & 44.7 & 55.3 \\
\hline "Source: State Statistical Office [14]. & &
\end{tabular}

In order to accomplish the study objectives, a major program of field research was carried out, through face to face interviews, using a questionnaire as a tool for data collection. The length of the face to face interviews was approximately 60 minutes (according to the circumstances) and was conducted in either Macedonian or Albanian, depending on the participant's preferences. To increase the participant's privacy and protection, respondents were asked if 
they have a place in their own home where they could talk privately.

The selected field researchers were psychologists, psychiatrists, social workers, anthropologists, pedagogyists and other relevant professionals. All were trained in: usage of the Consent Letter and Questionnaires; participant recruitment in their selected catchment area, male/female, ethnicity, town/village; usage of the MMSE; elder maltreatment; available SOS phone line.

\section{Data Analysis/Analytic Strategy}

A number of statistical techniques were used to answer the research questions. Applied was crosstabulations with chi-square analysis, binary logistic regression. Statistical significance was set at $p<.05$ for all analyses. First, chi-square analysis, were used to evaluate the associations between abuse and risk factors, by identifying significant relationships. Second, variables that were significantly related to abuse were included in the next step of the analysis. Of all these significant predictors, we were interested to see which predictors were most important. Therefore, we used a logistic regression. Predictors of the occurrence of overall abuse (yes or no) were examined with a binary logistic regression.

For binary logistic regressions, odds ratios have been reported. These odds ratios describe the probability of an older individual experiencing abuse divided by the probability that she experiences no abuse. An odds ratio close to 1 indicates that the independent variable does not affect the dependent variable. Odds ratios greater than 1 refer to an increase in the likelihood of the dependent variable with a one unit increase in a predictor variable [19].

\section{Results}

The prevalence rates obtained show that 307 $(32.0 \%)$ of the total number of participants reported that they had suffered abuse or neglect. From $32 \%$, $19.4 \%$ were female and $12.6 \%$ were male.

Table 2: Overall prevalence rates of abuse/neglect.

\begin{tabular}{lccc}
\hline Prevalence of abuse/neglect & Total \% & Male \% & Female \% \\
\hline No abuse/neglect & 68.0 & 32.1 & 35.9 \\
Abused & 32.0 & 12.6 & 19.4 \\
Total & 100.0 & 44.7 & 55.3 \\
\hline
\end{tabular}

From the total number (percentage) of abused/neglected 307 (100\%), 38.9\% were male and $61.1 \%$ were female, actually 1.6 times females are often that male exposed to abuse.

Psychological abuse was the most frequently reported among male and female respondents $(25.7 \%)$, from all (960) respondents, followed by financial abuse (12.0\%), physical abuse (5.7\%), neglect $(4.7 \%)$, physical injury $(3.1 \%)$ and sexual abuse $(1.3 \%)$ reported only by female. As it can be seen in the Table 3, female respondents are almost twice and more exposed to abuse and neglect than male respondents. $16.2 \%$ are exposed on psychological abuse, $4 \%$ on physical abuse, $2.3 \%$ on physical injuries, $6.5 \%$ on financial abuse, 4.7 on neglect and only female respondents have been exposed on sexual abuse.

Table 3: Prevalence of different types of abuse/neglect.

\begin{tabular}{lccc}
\hline Type of abuse $(\mathrm{N}=960)$ & Total $\%$ & Male $\%$ & Female $\%$ \\
\hline Psychological abuse & 25.7 & 9.5 & 16.2 \\
Physical abuse & 5.7 & 1.7 & 4.0 \\
Physical injury & 3.1 & 0.8 & 2.3 \\
Financial abuse & 12.0 & 5.5 & 6.5 \\
Sexual abuse & 1.3 & 0 & 1.3 \\
Neglect & 6.6 & 1.9 & 4.7 \\
\hline
\end{tabular}

From the data given in Table 4, the percentage of non-abused men was higher than those who experienced abuse. In contrast, the percentage of female respondents who experienced abuse was higher than those who had not experienced abuse.

Table 4: Gender and abuse/neglect.

\begin{tabular}{lcc}
\hline Gender & No abuse/neglect \% & Abuse $/$ neglect \% \\
\hline Male $^{\star}$ & 47.2 & 39.4 \\
Female $^{*}$ & 52.8 & 60.6 \\
Total & 100.0 & 100.0 \\
\hline Value $\%{ }^{*} \mathrm{p}<0.05$. & &
\end{tabular}

Chi square was 5.06 which is on 0.05 level of statistically significance.

Being female is a relevant risk factor for being exposed on every type of abuse, except financial. There is no data for sexual abuse as there was no man who reported that he experienced such type of abuse.

Table 5: Gender as a risk factor for elder abuse (Odds ratio).

\begin{tabular}{lllllll}
\hline Gender & $\begin{array}{l}\text { Abuse/ } \\
\text { neglect }\end{array}$ & $\begin{array}{l}\text { Psychological } \\
\text { abuse }\end{array}$ & $\begin{array}{l}\text { Physical } \\
\text { abuse }\end{array}$ & $\begin{array}{l}\text { Physical } \\
\text { injuries }\end{array}$ & $\begin{array}{l}\text { Financial } \\
\text { abuse }\end{array}$ & Neglect \\
\hline $\begin{array}{l}\text { Female/ } \\
\text { male }\end{array}$ & $1.372^{*}$ & $1.496^{* *}$ & $2.045^{*}$ & $2.274^{*}$ & 0.997 & $2.113^{* *}$ \\
\hline Binary Logistic Regression coefficient ${ }^{*} \mathrm{p}<0.05$ and ${ }^{* *} \mathrm{p}<0.01$. & &
\end{tabular}

Older women were more likely to be abused in the last 12 months than older men in general. Particularly older women are 1.5 times more likely to be victims of psychological abuse, 2 times more likely to be victims of physical abuse, 2.3 times more likely to be victims of physical injuries, and 2.1 times more likely to be victims of neglect than older men.

Data obtained with statistical analyze confirm the main hypothesis that gender is a relevant risk factor for psychological abuse, physical abuse, physical injuries, sexual abuse and neglect, but not for financial elderly abuse.

The profile of the potential victim for elderly abuse according the Macedonian study will be female who is: widowed $53.5 \%$ of female respondents who reported any type of abuse was widowed, 37.5\% married, $4 \%$ divorced and $5 \%$ were single); on the age between 65 and 74 years $(56.8 \%$ of female respondents who reported any type of abuse were on 
the age between 65 and $75,38.7 \%$ were on the age between 75 and 84 , and $4.5 \%$ on the age up to 85 years); living with relatives $(30.1 \%$ of abused female are living with relatives, $22.2 \%$ of abused female are living with their children, alone $21 \%, 15.3 \%$ with husbands and $8.52 \%$ with husband and children), without sufficient accommodation: own room, heating cooling, etc $(53.4 \%$ of female respondents who reported any type of abuse or neglect do not have sufficient accommodation); having chronicle diseases (61.3\% of abused female respondents reported that they are suffering from cardiovascular diseases, and $68.8 \%$ are suffering from rheumatic diseases). It should be noticed here, that $57.9 \%$ of all (abused and non abused) female respondents reported suffering from cardiovascular diseases and $67.4 \%$ from rheumatic diseases. Other diseases are not so frequently reported, for example: asthma (9.1\%), allergy $(15.1 \%)$, diabetes $(26.8 \%)$, psychical diseases $(15.7 \%)$, etc.

\section{Discussion}

There are many surveys which have been focused on elder abuse and neglect. A review of such surveys showed that prevalence of elder abuse has been estimated in different settings and various methods for data collection have been used [20]. Existing evidence in most of the studies indicates that abused older people are more likely to be female, cognitively impaired, in poor physical health, and dependent on other people [21-23].

Being female is a relevant risk factor for elder maltreatment in Macedonian study too. In Macedonian study women are 1.6 times often victims of abuse than man. Findings obtained in this survey simply followed the general tendency in violence toward elder women in the world. Studies from other countries showed that women are often victims of abuse: in Spain study [24] it is almost twice as (63.2\%) than men $(36.8 \%)$, New Zealand study reported that $2 / 3$ of abused older people are women. Even taking account of the fact that there are 6 women over the age of 65 for every 5 men, women are over-represented as victims of elder abuse [25].

Women make up approximately $66 \%$ of elder abuse victims in the United States, and $89 \%$ of the cases of abuse occurred in a domestic setting [26].

Croatian study reported that in the partner relationship among elderly, $44 \%$ of the women and $35 \%$ of the men had experienced at least some form of violence [27].

In UK study also, women were significantly $(90 \%)$ more likely to have experienced mistreatment than men: $3.8 \%$ of women and $1.1 \%$ of men reported mistreatment in the past year. When neglect was excluded, the prevalence rate for abuse continued to be significantly higher for women $(2.3 \%)$ compared to men $(0.6 \%)$. Women were significantly more likely than men to have experienced neglect and interpersonal abuse (physical, psychological, and sexual forms), whereas the prevalence of financial abuse was similar for both sexes [28].

In prevalence study from Ireland, women $(2.4 \%)$ were more likely than man $(1.9 \%)$ to report maltreatment, especially financial and interpersonal [29].

To address abuse of older women, "The prevalence study of abuse and violence against older women" (AVOW) was conducted in five European countries (Austria, Belgium, Finland, Lithuania and Portugal). Study showed that $28 \%$ of older women aged between 60 and 90 years living in private households in Europe have experiences violence or abuse in the last 12 months.

According to Spain study [24] elder women were about twice as likely as men to report verbal abuse but did not differ in the odds of reporting financial abuse. Elder women experience sexual/physical assault almost three times more than men [30], congruent to the theoretical expectations and the findings of previous research [31].

In Macedonian study the prevalence of elderly woman abuse and neglect showed that psychological abuse was the most common form of abuse (16.2\%), followed by financial abuse (6.5\%), neglect $(4.7 \%)$, physical abuse $(4.0 \%)$, and physical injury (2.3\%). Sexual abuse reported only female respondents (1.3\%). Findings from Macedonian study are similar with these obtained from AVOW [11] study (emotional abuse was the most common form of abuse experienced $(23.6 \%)$, followed by financial abuse $(8.8 \%)$, violation of rights $(6.4 \%)$ and neglect $(5.4 \%)$. Sexual abuse $(3.1 \%)$ and physical abuse $(2.5 \%)$ were the least reported forms).

In Macedonian study only in financial abuse gender (being female) is not the relevant risk factor for being abused. Male and female respondent have been equally exposed to financial abuse.

The general conclusion conducted from all mentioned study as well as Macedonian study to is that women are more likely to be victims because they live longer and are more likely to be living alone and also they are more likely to be victims of continuing domestic violence [32].

It is very important to notice here that gender and abuse cannot be seen in isolation and need to be analyzed within the ecological model in order to avoid single or biased interpretations [33-35].

Although both domestic violence and elder abuse research would be expected to cover the abuse of older women, researchers often exclude these victims from their target populations $[36,37]$ reinforcing the perception of older women as frail and sexless. 
Defining the specifics of elderly abuse and neglect in our country can facilitate support of abused older female and, most importantly, can help in developing policy and programmes targeted to prevention and response. Coordination between scientists and practitioners can improve decisionmaking in prevention of and response to elder abuse and neglect in general.

\section{References}

1. Eurostat. The life of women and men in Europe. Statistical portrait. Luxembourg: Office of the Official Publications of European Communities, 2008.

2. European Parliament. Report on the role of women in an ageing society: Committee on Women's Rights and Gender Equality, 2010.

3. Active ageing: a policy framework. Geneva, World Health Organization, 2002 (WHO/NMH/NPH/02.8).

4. Krug $E$ et al., eds. World report on violence and health. Geneva, World Health Organization, 2002. http://www.who.int/violence_injury_prevention/violence/world_r eport/en. Accessed 27, June 2012.

5. World Health Organization. Definition of an older or elderly person. Geneva, WHO, $2012 . \quad$ www. who.int/healthinfo/survey/ageingdefnolder/en/index.html. Accessed 29 November, 2012.

6. WHO/INPEA. Missing voices: views of older persons on elder abuse. Geneva, World Health Organization, 2002 http://whqlibdoc.who.int/hq/2002/WHO_NMH_VI P_02.1.pdf. Accessed 12 December, 2011.

7. National Committee for the Prevention of Elder Abuse \& MetLife Mature Market Institute. The essentials: preventing elder abuse. New York, 2012 https://www.metlife.com/assets/cao/mmi/publications/essential $\mathrm{s} / \mathrm{mmi}$-preventing-elder-abuse-essentials.pdf. Accessed 8 October, 2012.

8. Здружение за еманципација, солидарност и еднаквост на жените на PM - ECE [Association for Emancipation, Solidarity and Equality of Women in the Republic of Macedonia]. (2006) Животот во сенка [Life in shadow]. Skopje, Macedonia: Author.

http://www.semejnonasilstvo.org.mk/Root/mak/_docs/Zivot\%2 Ovo\%20senka\%20-\%20broshura.pdf. Accessed Jun 12, 2012.

9. Bronfenbrenner U. Ecological model of human development In: Husen $\mathrm{T}$, Postlethwaite $\mathrm{TN}$, eds. International Encyclopaedia of Education (2nd ed., vol. 3). Oxford, Pergamon Press, 1993:1643-1647.

10. ABUEL, abuse of elderly in Europe. The Project. Luxembourg, ABUEL, EU Executive Agency for Health and Consumers, 2009. abuel.org/project.html. Accessed 9 October 2011.

11. National Institute for Health and Welfare. Prevalence study of violence and abuse against older women (AVOW). Helsinki, National Institute for Health and Welfare, 2011. http://www.thl.fi/avow. Accessed 9 October, 2011.

12. Sheik JI, Yesavage JA. Geriatric Depression Scale (GDS): recent evidence and development of a shorter version. In: Brink TL, ed. Clinical gerontology: a guide to assessment and intervention. New York, Haworth Press, 1986:165-173.

13. Raspopovic ED. Gerijatrijska skala za depresiju (Kratka Forma) [Geriatric Depression Scale (short form)]. Belgrade, Clinical Centre of Serbia (no date). http://www.stanford.edu/ yesavage/Serbian.html. Accessed 20 October, 2011.
14. State Statistical Office. Estimation of population on 30.06.2010 and 31.12.2010 according to the gender by municipality and statistical regions. Skopje, State Statistical Office, Republic of Macedonia, http://www.stat.gov.mk/publikacii/2.4.11.14.pdf Macedonian). Accessed 20 November, 2011.

15. Адресар на општини во Република Македонија. [Address book municipalities in Macedonia]Skopje, Macedonian Centre for International Cooperation, 2006.

16. Krsteska R. Mini Mental Test kaj Alchajmerova i vaskularna demencija. [Mini Mental Test in Alzheimer's and vascular dementia.] Makedonski Medicinski Pregled [Macedonian Medical Review], 2007, 1-3:1-96.

17. Kurlowicz L, Wallace M. The Mini Mental State Examination (MMSE). Hartford Institute for Geriatric Nursing, 1999 (Try This: Best Practices in Nursing Care to Older Adults, No. 3, January1999).http://www.dhs.state.or.us/spd/tools/cm/aps/ass essment/mini_mental.pdf. Accessed 16 January, 2013.

18. The Mini Mental State Examination (MMSE). London, Alzheimer's Society, 2012. http://www.alzheimers.org.uk/site/scripts/documents_info.php? documentID =121. Accessed 9 October, 2012.

19. Field Andy, Discovering Statistics Using SPSS for Windows: Advanced Techniques for Beginners. SAGE Publications, 2000.

20. Lowenstein, A, et al. Is elder abuse and neglect a social phenomenon? Data from the first national prevalence survey in Israel. Journal of Elder Abuse and Neglect, 2009. 21:253-277. http://dx.doi.org/10.1080/08946560902997629. Accessed October 4, 2012.

21. Namkee, G.C. \& Mayer, J. Elder abuse, neglect and exploitation: risk factors and prevention strategies. Journal of gerontological social work, $2000 . \quad 33: 2$. www.tandfonline.com/doi/abs/101300/J083v33n02_02\#previev Accessed October 11, 2011.

22. Bonie, R.J. \& Wallace R.B. (Eds.). Elder Mistreatment. Abuse, Neglect and Exploitation in an Aging America. Washington DC, Washington: The national Academies Press, 2003. http://www.nap.edu/openbook.php?record_id=10406\&page $=\mathrm{R}$ 1. Accessed April 15, 2013.

23. Barker, N.N., \& Himchak, M.V. Environmental issues affecting elder abuse victims in their reception of community based services. Journal of Gerontological Social Work, 2006. 48(12):233-255.

24. Marmolejo II. Elder abuse in the family in Spain. Valencia: The Queen Sofia Center Study, 2008 www.inpea.net/images/Spain_Report_2008_Elder.pdf. Accessed September 21, 2012.

25. Age Concern New Zealand 2012, www.ageconcern.org.nz. Accessed September 15, 2012.

26. The 2004 Survey of State Adult Protective Services: Abuse of Adults 60+. National Committee for the Prevention of Elder Abuse and NAPSA. 2004. http://www.napsa-now.org/wpcontent/uploads/2012/09/2-14-06-FINAL60+REPORT.pdfAccessed October 18, 2013.

27. Ajdukovic M, Ogresta $J$ \& Rusac S. Family Violence and Health Among Elderly in Croatia, Journal of Aggression, Maltreatment \& Trauma, 2009. 18:3, 261279.http://dx.doi.org/10.1080/10926770902835873. Accessed November 15, 2013.

28. Biggs S, Manthorpe J, Tinker A, Doyle $M$ \& Erens B.Mistreatment of Older People in the United Kingdom: Findings from the First National Prevalence Study, Journal of Elder Abuse \& Neglect, 2009, 21:1, 1-14. http://dx.doi.org/10.1080/08946560802571870. Accessed May $11,2013$.

29. Sethi D et al., eds. European report on preventing elder 
maltreatment. Copenhagen, WHO Regional Office for Europe,

2011.

http://www.euro.who.int/_data/assets/pdf_file/0010/144676/e

95110. Pdf. Accessed 29 November 2012.

30. Report of the UNECE Ministerial Conference on Ageing. "A society for all ages: challenges and opportunities". Geneva, United Nations Economic Commission for Europe, 2007 http://www.unece.org/fileadmin/DAM/pau/_docs/ece/2007/ECE AC30_2007_2.e.pdf. Accessed 29, November 2012.

31. Belinger E, Davis C, Fulmore C. Elder abuse: what professionals need to know. Pittsburgh, University of Pittsburgh School of Social Work, 2010 http://www.socialwork.pitt.edu/downloads/Elder\%20Abuse\%20 Project.pdf. Accessed 10, February 2012.

32. National Center on Elder Abuse-- - "A Response to the Abuse of Vulnerable Adults: - The 2000 Survey of State Adult Protective Services":

http://www.elderabusecenter.org/whatnew/vulnerableadults.pdf Accessed January 16, 2014.

33. McCreadie C. Elder abuse: update on research. London, Age Concern and Institute of Gerontology, King's College, 1996.

34. Bennett G, Kingston P, Penhale, B. The dimensions of elder abuse: perspectives for practitioners. London, Macmillan, 1997.

35. Hudson MF. Elder mistreatment: its relevance to older women. Journal of the American Medical Women's Association. 1997; 52:142-146, 158.

36. Phillips LR. Domestic violence and aging women. Geriatric Nursing. 2000; 21:188-193.

37. Brandl B, Cook-Daniels L. Domestic abuse in later life. Violence Against Women Online Resources, 2002 http://www.vawnet.org/

DomesticViolence/Research/VAWnetDocs/AR later-life.pdf. Accessed June 6, 2005. 